\title{
ANALISIS KOMPARATIF PENDAPATAN PETANI KAKAO YANG MENJUAL BIJI KERING DENGAN BIJI BASAH DI DESA PANCA KARSA I KECAMATAN TALUDITI KABUPATEN POHUWATO
}

\section{Comparative Analysis Of Cocoa Farmers Income Selling Dry Seeds With Wet Seeds In Panca} Karsa I Village, Taluditi District, Pohuwato Regency

\author{
Fatmawati $^{1)}$, Yulan Ismail ${ }^{2)}$, Pitri Rasid ${ }^{3)}$ \\ Email:fathyafath.ff@gmail.com
}

Program Studi Agribisnis, Fakultas Pertanian, Universitas Ichsan Gorontalo ${ }^{123)}$

\begin{abstract}
Abstrak
Tujuan penelitian ini adalah (1) untuk mengetahui pendapatan petani kakao yang menjual biji kering dengan biji basah di Desa Panca Karsa I Kecamatan Taluditi Kabupaten Pohuwato, serta (2) untuk mengetahui perbandingan pendapatan petani dalam menjual biji basah dengan biji kering di Desa Panca Karsa I Kecamatan Taluditi Kabupaten Pohuwato. Penelitian ini dilaksanakan di Desa Panca Karsa I Kecamatan Taluditi Kabupaten Pohuwato. Analisis yang digunakan adalah analisis pendapatan dan analisis perbandingan pendapatan. Hasil penelitian menunjukkan bahwa (1) Rata-rata pendapatan petani yang menjual biji kakao kering sebesar Rp 9.796.705,87 dan pendapatan petani yang menjual biji kakao basah sebesar Rp 6.000.425,00. (2) Perbandingan pendapatan petani yang menjual biji kakao kering dengan petani yang menjual biji kakao basah nilai t hitung sebesar 1,205. Nilai t hitung $(1,205)<t$ tabel $(1,697)$ dan nilai Sig. $(0,931)>\alpha(0,05)$. Artinya tidak ada perbedaan yang signifikan antara pendapatan petani yang menjual biji kakao kering dengan biji kakao basah.
\end{abstract}

Kata kunci: biji basah, biji kering, komparatif, pendapatan

\begin{abstract}
The purpose of this study was (1) to determine the income of cocoa farmers who sell dried beans with wet beans in Panca Karsa I Village, Taluditi District, Pohuwato District, and (2) to determine the comparison of farmers' income in selling wet beans with dry seeds in Panca Karsa I Village Taluditi District, Pohuwato Regency. This research was conducted in Panca Karsa I Village, Taluditi District, Pohuwato Regency. The analysis used is income analysis and income comparison analysis. The results showed that (1) The average income of farmers who sold dried cocoa beans was Rp 9,796,705.87 and the income of farmers who sold wet cocoa beans amounted to Rp 6,000,425.00. (2) Comparison of the income of farmers who sell dried cocoa beans with farmers who sell wet cocoa beans, the $t$ value is 1.205. T value (1.205) <t table (1.697) and Sig. (0.931) $>\alpha$ (0.05). This means that there is no significant difference between the income of farmers who sell dried cocoa beans and wet cocoa beans.
\end{abstract}

Keywords: wet seeds, dry seeds, comparative, income

\section{PENDAHULUAN}

Kakao (Theobroma cacao L) merupakan salah satu komoditas andalan perkebunan yang memiliki peranan cukup penting bagi perekonomian nasional, khususnya sebagai penyedia lapangan kerja, sumber pendapatan dan devisa negara, di samping kelapa sawit dan karet. Food and Agriculture Organization (FAO) menyatakan bahwa Indonesia menempati urutan ketiga sebagai negara penghasil kakao dunia setelah Pantai Gading dan Ghana. Melihat kondisi tersebut tidaklah mengherankan apabila pemerintah 
memberikan perhatian khusus terhadap upaya peningkatan produksi kakao nasional guna memenuhi kebutuhan domestik maupun ekspor (Zakiya, 2012).

Produksi kakao mengalami peningkatan permintaan terus. Hal ini dapat dilihat dari semakin berkembangnya industri yang pada akhirnya akan meningkatkan permintaan kakao sebagai tambahan makanan dan minuman. Produksi kakao nasional memiliki persebaran hampir di seluruh propinsi di Indonesia. Berdasarkan data statistik yang dikeluarkan oleh Direktorat Jenderal Perkebunan diketahui bahwa luas areal perkebunan kakao nasional saat ini adalah 1.691.334 Ha. Jika dilihat dari kurun waktu tahun 2013 hingga tahun 2016 komoditi kakao nasional mengalami penurunan yakni luas areal menurun $1,05 \%$ dan produksi menurun 2,19\% $\mathrm{kg} / \mathrm{ha}$. Selain dampak dari alih fungsi areal perkebunan kakao diperkirakan penurunan produksi disebabkan oleh faktor perubahan iklim serta belum maksimalnya pemeliharaan tanaman (Direktorat Jenderal Perkebunan Nasional, 2017).

Desa Panca Karsa 1 mayoritas penduduknya petani kakao dimana Kecamatan Taluditi juga termasuk sebagai wilayah pengembangan produktivitas kakao di Kabupaten Pohuwato. Perbedaan cara menjual kakao di Desa Panca Karsa I menyebabkan adanya perbedaan pendapatan petani kakao. Kakao yang dijual basah yaitu biji kakao dibelah untuk diambil bijinya tanpa dijemur terlebih dahulu dan biji kakao yang dijual kering yaitu kakao yang sudah dijemur terlebih dahulu dengan memanfaatkan sinar matahari. Biji kakao yang masih basah langsung dijual oleh petani dikarenakan beberapa alasan, diantaranya faktor waktu yang dirasa petani lama dalam proses penjemuran, tenaga kerja yang dibutuhkan dalam proses penjemuran, dan faktor cuaca yang tidak menentu sehingga sulit dalam proses penjemuran.

Biji kakao basah diperoleh dari buah kakao. Buah kakao bisa dipanen apabila perubahan warna kulit dan setelah fase pembuahan sampai menjadi buah dan matang usia 5 bulan. Ciri-ciri buah yang akan dipanen adalah warna kuning pada alur buah, warna kuning pada punggung alur buah, warna kuning pada seluruh permukaan buah dan warna kuning tua pada seluruh permukaan buah (Badan Litbang Pertanian, 2013).

Biji kakao kering yaitu biji kakao yang digunakan diambil dari buah kakao masak, yaitu buah yang telah berwarna kuning atau oranye dan mengeluarkan bunyi berongga ketika diketuk. Buah dicuci dengan air kemudian dibelah untuk di keluarkan bijinya dan dikeringkan bijinya dan dikeringkan pada tampi bambu dibawah sinar matahari langsung sampai 
pada kandungan airnya tersisa 6 sampai 7\% (Widianto, Donny dkk. 2013).

Pendapatan petani merupakan ukuran penghasilan yang diterima oleh petani dari usahataninya. Dalam analisis usahatani, pendapatan petani digunakan sebagai indikator penting karena merupakan sumber utama dalam mencukupi kebutuhan hidup sehari-hari. Pendapatan merupakan suatu bentuk imbalan untuk jasa pengelolaan yang menggunakan lahan, tenaga kerja, dan modal yang dimiliki dalam berusahatani. Kesejahteraan petani akan lebih meningkat apabila pendapatan petani menjadi lebih besar, yaitu jika petani dapat menekan biaya yang dikeluarkan serta diimbangi dengan produksi yang tinggi dan harga yang baik. Pengaruh harga dan produktivitas yang berubah-ubah mengakibatkan pendapatan petani ikut berubah pula harga dan produktivitas merupakan faktor ketidakpastian dalam kegiatan usahatani (Hernanto, dan Soekartawi, 2005).

Pendapatan dapat dibedakan menjadi dua, yaitu pendapatan usahatani dan pendapatan keluarga. Pendapatan merupakan pengurangan dari penerimaan dengan biaya total. Pendapatan keluarga, yaitu pendapatan yang diperoleh dari kegiatan usahatani ditambah dengan pendapatan yang berasal dari kegiatan diluar usahatani. Pendapatan usahatani adalah selisih antara pendapatan kotor (output) dan biaya produksi (input) yang dihitung per bulan, per tahun, atau per musim tanam.Pendapatan usahatani dapat dibagi menjadi dua pengertian, yaitu:

1. Pendapatan kotor, yaitu seluruh pendapatan yang diperoleh petani dalam usahatani selama satu tahun yang dapat diperhitungkan dari hasil penjualan atau pertukaran hasil produksi yang dinilai dalam rupiah berdasarkan harga per satuan berat pada saat pemungutan hasil.

2. Pendapatan bersih, yaitu seluruh pendapatan yang diperoleh petani alam satu tahun dikurangi dengan biaya produksi selama proses produksi.

\section{BAHAN DAN METODE WAKTU DAN LOKASI PENELITIAN}

Penelitian ini dilaksanakan di Desa Panca Karsa I Kecamatan Taluditi Kabupaten Pohuwato Provinsi Gorontalo. Penelitian ini akan dilakukan selama tiga bulan dari November 2017 sampai dengan bulan Januari 2018.

\section{POPULASI DAN SAMPEL}

Populasi adalah keseluruhan dari subyek penelitian. Berdasarkan pendapat tersebut, maka dalam penelitian ini yang menjadi populasi adalah keseluruhan petani kakao yang berada di Desa Panca Karsa 1 Kecamatan Taluditi dengan 
jumlah 95 yang menjual biji basah, dan 155 yang menjual biji kering dengan jumlah keseluruhan populasi 250 petani kakao.

Sampel adalah sebagian atau wakil populasi yang diteliti. Definisi sampel merupakan suatu bagian dari populasi yang akan diteliti dan dianggap dapat mengambarkan populasinya (Soehartono,2004). Teknik pengambilan sampel dengan carastratified random sampling (sampel acak berstrata). Penentuan jumlah sampel menggunakan teknik Slovin, dengan rumus:

Keterangan:

$$
n=\frac{N}{1+N e^{2}}
$$

$\mathrm{n}=$ sampel

$\mathrm{N}=$ populasi

$\mathrm{e}=$ tingkat kesalahan $(15 \%)$

Jumlah sampel dalam penelitian ini yaitu 37 petani kakao. Sampel terdiri dari 14 petani kakao yang menjual biji basah dan 22 petani kakao yang menjual biji kering.

\section{METODE PENGAMBILAN DATA}

\section{Teknik Observasi dan Wawancara}

Teknik observasi merupakan teknik yang digunakan untuk mengumpulkan data melalui pengamatan langsung terhadaplokasi yang akan diteliti. Dengan observasi dapat diperoleh gambaran yang jelas tentang kehidupan sosial. Teknik ini digunakan untuk mengamati atau wawancara secara berhadapan langsung dengan mengungkapkan pertanyaanpertanyaan. Alat ini digunakan untuk mengetahui dan memproleh data yang beisi sejumlah pertanyaan yang di isi oleh penelitian berdasarkan hasil jawaban yang di peroleh dari responden di lapangan.

\section{Teknik Kuesioner}

Kuesioner digunakan untuk memperoleh data tentang jumlah anak, jumlah tanggungan keluarga, luas lahan milik, produksi kakao, tingkat pendapatan, dan tingkat pemenuhan kebutuhan pokok kepada responden terutama kepada kepala keluarga petani kakao di Desa Pancakarsa 1.

\section{ANALISIS DATA}

Analisis data adalah proses penyederhanaan data kedalam bentuk yang lebih mudah dibaca dan diinterpretasikan. Teknik analisis data yang digunakan dalam penelitian ini yaitu analisis data kuantitatif persentase yaitu dalam bentuk tabel tunggal. Setelah data ditabulasikan dan dipersentasekan, selanjutnya deskripsikan secara sistematis dan diinterprestasikan dalam membuat laporan sebagai hasil penelitian dan ditulis kesimpulan seba gai hasil akhir laporan penelitian (Efendi, 1989).

1. Untuk menghitung penerimaan digunakan dengan rumus:

$$
\mathrm{TR}=\mathrm{Q} \text {. PX }
$$

Keterangan: 
$\mathrm{TR}=$ Penerimaan produksi atau pendapatan kotor $(\mathrm{Rp})$

$$
\begin{array}{ll}
\mathrm{Q} & =\text { Produksi }(\mathrm{Kg}) \\
\mathrm{Px} & =\operatorname{Harga}(\mathrm{Rp})
\end{array}
$$

2. Untuk menghitung pendapatan usaha tani digunakan rumus:

$$
\mathrm{I}=\mathrm{TR}-\mathrm{TC}
$$

Keterangan:

$$
\begin{array}{ll}
\mathrm{I} & =\text { Pendapatan }(\mathrm{Rp}) \\
\mathrm{TR} & =\text { Penerimaan total }(\mathrm{Rp}) \\
\mathrm{TC} & =\text { Biaya total }(\mathrm{Rp})
\end{array}
$$

3. Untuk menghiitung perbandingan digunakan rumus:

$$
\mathrm{t}=\frac{X 1-X 2}{s X 1-X 2}
$$

keterangan:

$\mathrm{X}_{1} \quad=$ rata-rata variabel 1

$$
\mathrm{X}_{2} \quad=\text { rata-rata variabel } 2
$$

S

$$
=\text { rata-rata standar }
$$

deviasi variabel atau kekeliruan baku

kriteria uji:

$\mathrm{t}$ hitung $>\mathrm{t}$ tabel $\mathrm{H} 0$ diterima $\mathrm{H} 1$ ditolak

$\mathrm{t}$ hitung $<\mathrm{t}$ tabel $\mathrm{H} 0$ ditolak, $\mathrm{H} 1$ diterima

\section{HASIL DAN PEMBAHASAN IDENTITAS PETANI RESPONDEN KLASIFIKASI UMUR RESPONDEN}

Umur sangat berpengaruh pada pola pikir petani.Semakin tua umur seseorang maka petani tersebut kurang produktif dalam mengelola usahataninya. Sebaliknya petani yang memiliki umur muda produktif dalam mengelola usahataninya. Karateristik umur responden dapat dilihat pada Tabel 1 .

Tabel 1. Karakteristik Umur Responden Di Desa Panca Karsa I Kecamatan Taluditi Kabupaten Pohuwato Tahun 2018

\begin{tabular}{llcc}
\hline No & \multicolumn{1}{c}{ Umur (Tahun) } & Jumlah Respoden (orang) & Persentase $(\%)$ \\
\hline 1 & $22-30$ & 4 & 10,81 \\
2 & $31-39$ & 7 & 18,92 \\
3 & $40-49$ & 9 & 24,32 \\
4 & $50-59$ & 11 & 29,73 \\
5 & $60-69$ & 2 & 5,41 \\
6 & $>70$ & 4 & 10,81 \\
\hline & Jumlah & 37 & 100 \\
\hline
\end{tabular}

Sumber: Data primer setelah diolah, 2018

Berdasarkan Tabel 1 dapat dilihat petani responden didominasi oleh petani yang umurnya 50-59 tahun sebanyak 11 orang $(29,73 \%)$, sedangkan petani yang berumur 60-69 tahun sebanyak 2 orang $(5,41 \%)$ dengan angka terendah. Sehingga dapat disimpulkan petani yang ada di Desa Panca Karsa I Kecamatan Taluditi berada pada kategori umur produktif dengan total keseluruhan 31 orang petani kakao, berdasarkan pendapatan Patong dalam Jufri (2014) bahwa pengolompokan umur berdasarkan pada kriteria produktif dan non produktif. Kisaran umur 15-54 tahun tergolong usia produktif dan 55 tahun keatas dikategorikan usia non produktif. 


\section{KARAKTERISTIK \\ BERDASARKAN PENDIDIKAN RESPONDEN}

Tingkat pendidikan formal yang dimiliki petani akan menunjukan tingkat pengetahuan serta wawasan yang luas untuk petani menerapkan apa yang diperolehnya untuk peningkatan usahataninya. Mengenai tingkat pendidikan, dimana mereka yang berpendidikan tinggi relatif lebih cepat dalam melaksanakan adopsi inovasi. Untuk lebih jelasnya komposisi tingkat pendidikan responden dapat dilihat pada Tabel 2.

Tabel 2. Karakteristik Petani Kakao Berdasarkan Tingkat Pendidikan di Desa Panca Karsa I Kecamatan Taluditi Kabupten Pahuwato tahun 2018.

\begin{tabular}{lcc}
\hline \multicolumn{1}{c}{ Tingkat Pendidikan } & Jumlah Responden (orang) & Persentase $(\%)$ \\
\hline Tidak Sekolah & 7 & 18,92 \\
SD & 20 & 54,05 \\
SMP & 4 & 10,81 \\
SMA & 6 & 16,22 \\
\hline Jumlah & 37 & 100 \\
\hline
\end{tabular}

Sumber: Data primer setelah diolah, 2018.

Berdasarkan Tabel 2 dapat diketahui bahwa tingkat pendidikan responden untuk yang tidak bersekolah 7 orang dengan $(18,92 \%)$, SD dengan jumlah responden sebanyak 20 orang $(54,05 \%)$, SMP dengan jumlah responden 4 orang $(10,81 \%)$, SMA dengan jumlah responden 6 orang $(16,22 \%)$. Sehingga dapat disimpulkan tingkat pendidikan responden berada pada kategori rendah. Dengan total keseluruhan 38 orang responden.

Tabel 3. Karakteristik Petani Kakao Berdasarkan Jumlah Tanggungan Keluarga di Desa Panca Karsa I Kecamatan Taluditi Tahun 2018.

\begin{tabular}{ccc}
\hline Tanggungan Keluarga & Jumlah Responden (orang) & Persentase (\%) \\
\hline $1-2$ & 5 & 13,51 \\
$3-4$ & 26 & 70,27 \\
$>5$ & 6 & 16,20 \\
\hline Jumlah & 37 & 100 \\
\hline
\end{tabular}

Sumber :Data primer setelah diolah, 2018
Jumlah tanggungan keluarga menggabarkan besar kecilnya sumber tenaga kerja keluarga yang tersediah, tetapi dapat pula menjadi beban keluarga terlebih jika anggota dalam keluarga tersebut belum masuk pada usia produktif. Berikut ini jumlah tanggungan keluarga responden dapat dilihat pada Tabel 3.

\section{KARAKTERISTIK PETANI BEDASARKAN JUMLAH TANGGUNGAN KELUARGA}


Berdasarkan pada Tabel 3 pada karakteristik responden berdasarkan jumlah tanggungan keluarga menunjukan bahwa yang paling mendominasi 3-4 jumlah tanggungan keluarga dengan jumlah responden 26 orang $(70,27 \%)$ selanjutnya jumlah tanggungan lebih dari 5 orang sebanyak 6 orang $(16,20 \%)$ dan $1-2$ tanggungan keluarga sebanyak 5 orang $(13,51 \%)$.

\section{KARAKTERISTIK BEDASARKAN BERUSAHATANI}

Pengalaman berusaha tani seseorang berpengaruh dalam menerima inovasi dari luar. Petani yang sudah lama bertani akan lebih muda menerapkan inovasi dari pada petani pemula atau petani baru. Petani yang sudah lama berusaha tani akan lebih menerapkan anjuran penyuluhan demikian pula dengan penerapan teknologi. Pengalaman berusahatani responden dapat dilihat pada Tabel 4.

Tabel 4. Karakteristik Petani Kakao Berdasarkan Pengalaman Berusaha Tani di Desa Panca Karsa I Kecamatan Taluditi, 2018

\begin{tabular}{ccc}
\hline Lama Berusaha Tani (Tahun) & Jumlah Responden (orang) & Persentase $(\%)$ \\
\hline $2-8$ & 4 & 10,81 \\
$9-15$ & 5 & 13,51 \\
$16-22$ & 9 & 24,32 \\
$23-29$ & 8 & 21,62 \\
$30-37$ & 10 & 27,03 \\
$>37$ & 1 & 2,70 \\
\hline Jumlah & 37 & 100
\end{tabular}

Sumber :data primer setelah diolah, 2018

Berdasarkan pada Tabel 4 pada karakteristik pengalaman berusaha tani di Desa Panca Karsa I didominasi oleh responden yang memiliki lama berusaha tani 30-37 tahun sebanyak 10 orang responden $(27,03 \%)$ dan terendah untuk lama berusaha tani lebih dari 37 tahun dengan jumlah responden 1 orang $(2,70 \%)$.

\section{PENDAPATAN USAHATANI KAKAO BIJI BASAH DAN KAKAO BIJI KERING}

\section{a. Penerimaan}

Peneriman atau pendapatan kotor didefinisikan sebagai nilai produk total usaha tani dalam jangka waktu tertentu, baik yang dijual maupun yang tidak di jual. Pendapatan usaha tani kotor usahatani adalah ukuran hasil perolehan total sumber daya yang digunakan dalam usaha tani. Nisba seperti pengalaman kotor dalam satu kali proses produksi, penerimaan dapat dihitung untuk menunjukkan intensitas operasi usahatani merupakan keseluruhan uang yang diperoleh dari hasil penjualan kakao yang diukur dengan satuan rupiah.

Penerimaan usahatani kakao di Desa Panca Karsa I dihitung berdasarkan 
jumlah produksi dan hasil penjualan dua kali panen dalam kurun waktu satu bulan.
Penerimaan usaha tani kakao dapat dilihat pada Tabel 5.

Tabel 5. Rata-rata Penerimaan Usahatani Kakao Biji Basah dan Kakao Biji Kering Desa Panca Karsa I Kecamatan Taluditi, 2018.

\begin{tabular}{lccc}
\hline \multicolumn{1}{c}{ Uraian } & Produksi $(\mathrm{Kg})$ & Harga $(\mathrm{Rp})$ & Penerimaan $(\mathrm{Rp})$ \\
\hline Biji Basah & 985,00 & $9.850,00$ & $10.015 .000,00$ \\
Biji Kering & 657,65 & $19.911,76$ & $12.829 .411,76$ \\
\hline
\end{tabular}

Sumber: Data primer setelah diolah, 2018

Berdasarkan Tabel 5 dapat dilihat perbandingan harga/pendapatan pada petani kakao yang menjual biji kakao kering dan biji kakao basah, dengan jumlah produksi yaitu pada petani yang menjual biji kering sebesar 657,65 kg dengan harga penjualan Rp 19.911,76/kg penerimaan sebesar Rp 12.829.411,76. Sedangkan petani yang menjual biji kakao basah yaitu memperoleh produksi sebesar $985 \mathrm{~kg}$ dengan harga penjualan sebesar Rp 9.850/kg penerimaan sebesar $\mathrm{Rp}$ 10.015.000. sehingga dapat disimpulkan jumlah penerimaan petani kakao yang menjual biji kering lebih besar daripada petani yang menjual biji kakao basah. Dengan selisih harga Rp.2.814.411,76.

\section{b. Biaya Usahatani Kakao}

Biaya usahatani dibedakan menjadi dua yaitu biaya tetap (fixed cost) dan biaya tetap (variable cost). Biaya tetap adalah biaya yang relatif tetap jumlahnya, dan terus dikeluarkan walaupun jumlah produksi yang diperoleh banyak atau sedikit. Contoh biaya tetap antara lain sewa tanah, tenaga kerja, bibit, pupuk, obat-obatan dan tenaga kerja musiman, sihingga biaya ini sifatnya berubah-ubah tergantung dari besar kecilnya produksi yang diinginkan (Hanafie, 2010).

Pengeluaran atau biaya usahatani merupakan nilai penggunaan sarana produksi dan lain-lain yang dibebankan pada produk yang bersangkutan. Selain biayah tunai yang harus dikeluarkan, ada juga biaya yang diperhitungkan yaitu nilai pemakaian barang dan jasa yang dihasilkan dan berasal dari usahatani itu sendiri. Biayah yang diperhitungkan digunakan untuk menghitung seberapa besarnya pendapatan kerja petani kalau modal dan niali kinerja diperhitungkan, untuk lebih jelasnya dapat dilihat pada Tabel 6.

Tabel 6. Biaya usahatani kakao di Desa Panca Karsa I Kecamatan Taluditi Tahun 2017.

\begin{tabular}{|c|c|c|c|c|c|}
\hline Uraian & \multicolumn{2}{|c|}{ Biaya Tetap (Rp) } & \multicolumn{2}{|c|}{ Biaya Variabel $(\mathrm{Rp})$} & Total Biaya (Rp) \\
\hline Biji & Pajak & & Pupuk dan Pestisida & 2.361 .500 & \\
\hline Basah & Lahan & $40.000,00$ & Sarana dan Prasarana & 244.375 & $4.014 .575,00$ \\
\hline & & & Tenaga Kerja & 1.368 .700 & \\
\hline Biji & Pajak & 2511765 & Pupuk dan Pestisida & $1.386 .000,00$ & \\
\hline Kering & Lahan & $53.117,05$ & Sarana dan Prasarana & $207.764,71$ & $3.032 .105,89$ \\
\hline
\end{tabular}


Sumber: Data Primer setelah diolah, 2018

\section{Tenaga Kerja}

$1.403 .823,53$

Berdasarkan Tabel 6 Biaya usahatani petani kakao di Desa Panca Karsa I masing-masing memiliki perbedaan jumlahnya. Untuk biaya tetap petani yang menjual biji basah sebesar Rp.40.000 dan untuk petani yang menjual biji kering sebesar Rp.35.117,65. untuk penggunaan biaya variabel petani kakao yang menjual biji basah lebih besar biayanya dari pada petani yang menjual biji kakao kering. Dengan besaran biaya untuk petani yang menjual biji kakao basah Rp.4.014.575 dan untuk petani yang menjual biji kering Rp.3.032.705,89. dengan demikian penggunan biaya petani yang menjual biji kakao basah lebih besar dari pada petani yang menjual biji kering.

\section{c. Pendapatan}

Pendapatan usahatani adalah total pendapatan bersih yang diperolah dari seluruh aktivitas usahatani yang merupakan selisi antara total penerimaan dengan total biaya yang dikeluarkan. Menurut Soekartawi (2002), menguraika dan membagi pendapatan usahatani menjadi dua, yaitu pendapatan kotor usahatani (gross fram income) dan pendapatan bersih usahatani (net fram income). Pendapatan kotor usahatani yaitu nilai produk total usahatani dalam jangka waktu tertentu yang meliputi seluruh produk yang dihasilkan baik yang (1) dijual, (2) digunakan dalam usahatani untuk bibit, sarana dan prasarana dan (3) digunakan untuk pembayaran. Untuk menghitung nilai produk tersebut, harus dikalikan dengan harga pasar yang berlaku, yaitu dijual bersih diitingkat petani. Sementara pendapatan bersih usahatani adalah selisih antara pendapatan kotor usahatani dengan pengeluaran total usahatani.

Tabel 7. Rata-rata Penerimaan dan Pendapatan di Desa Panca Karsa I, 2018

\begin{tabular}{lccc}
\hline \multicolumn{1}{c}{ Uraian } & Penerimaan $(\mathrm{Rp})$ & Biaya $(\mathrm{Rp})$ & Pendapatan $(\mathrm{Rp})$ \\
\hline Biji Basah & $10.015 .000,00$ & $4.014 .575,00$ & $6.000 .425,00$ \\
Biji Kering & $12.829 .411,76$ & $3.032 .705,89$ & $9.796 .705,87$ \\
\hline
\end{tabular}

Sumber : Data primer setelah diolah, 2018

Berdasarkan Tabel 7 yang telah dianalisa sebelumnya dapat dilihat perbedaan pendapatan dari petani yang menjual biji basah maupun petani yang menjual biji kering. Petani yang menjual biji kering kakao lebih besar pendapatannya dibanding petani yang menjual biji kakao kering. Rata-rata pendapatan petani yang menjual biji kering sebesar Rp.9.796.705,87 dan untuk biji basah sebesar Rp. 6.000.425. 


\section{ANALISIS \\ KOMPARATIF \\ PENJUALAN BIJI KAKAO KERING DENGAN PENJUALAN BIJI KAKAO BASAH}

Analisis komparatif/perbandingan merupakan pengujian hipotesis yang dilakukan dengan menggunakan t-uji dua sampel independen separated varians (ragam pisah) (Ridwan 2003). Komparatif penjualan biji kakao kering dengan biji kakao basah disajikan Tabel 8.

Tabel 8. Komparatif penjualan biji kakao kering dengan biji kakao basah di Desa Panca Karsa

\begin{tabular}{|c|c|c|c|c|c|c|}
\hline $\begin{array}{c}\text { Penjualan } \\
\text { Kakao }\end{array}$ & $\mathrm{N}$ & $\begin{array}{c}\text { Std. } \\
\text { Deviation }\end{array}$ & $\mathrm{F}$ & Sig. & $\mathrm{t}$ & $\mathrm{df}$ \\
\hline Biji Kering & 17 & 9,56972E6 & 0,008 & 0,931 & 1,205 & 35 \\
\hline Biji Basah & 20 & 9,53829E6 & & & & \\
\hline
\end{tabular}

Sumber: Data Primer setelah diolah, 2018

Tabel 8 menunjukkan bahwa nilai t hitung sebesar 1,205. Nilai $\mathrm{t}$ hitung $(1,205)<\mathrm{t}$ Tabel $(1,697)$ dan nilai Sig. $(0,931)>\alpha$ $(0,05)$. Artinya tidak ada perbedaan yang signifikan antara pendapatan petani yang menjual biji kakao kering dengan biji kakao basah. Hal ini disebabkan karena perbedaan Rata-rata produksi yang berbeda antara biji kakao kering dengan basah. Rata-rata produksi biji kakao kering sebesar 657,65 kg dengan harga Rp. 19.911,76/kg. Sehingga diperoleh pendapatan Rp. 9.796.705,88. Sedangkan Rata-rata produksi biji kakao basah sebesar $985 \mathrm{~kg}$ dengan harga penjualan Rp. 9.850,-/kg. Sehingga diperoleh pendapatan Rp. 6.000.425,-

\section{FAKTOR-FAKTOR YANG MEMPENGARUHI ALASAN PETANI MENJUAL BIJI KAKAO BASAH DENGAN BIJI KAKAO KERING}

\section{Alasan Petani Menjual Biji Kakao Basah}

Petani kakao menjual biji kakao basah yaitu ingin perputaran uang yang lebih cepat dari pergantian musim yang tidak menentu dan dapat mempersingkat waktu petani dalam bekerja. Biji kakao basah yang dijual berupa perlakuan pasca panen yang tidak lagi mendapatkan perlakuan pada tahap pengeringan, setelah melakukan pemetikan, dibelah dan di bersihkan kemudian langsung dijual pada pengumpul dan tempat malakukan jual beli yaitu di rumah petani sendiri.

Sesuai dengan pendapat Kacaribu, dkk (2013) bahwa beberapa alasan petani menjual adalah banyaknya petani yang memerlukan perputaran uang hasil panennya secara cepat, jumlah hari hujan yang tidak menentu, upah tenaga kerja pada proses pengeringan, dan tidak tersedianya tempat penyimpanan coklat sehingga membuat resiko penurunan kualitas coklat semkin tinggi bila tidak langsung dijual. 


\section{Alasan Petani Menjual Biji Kakao Kering}

Petani menjual biji kakao kering karena harga pembeliannya yang cukup tinggi walaupun masih membutuhkan waktu dalalm proses penanganannya. Biji kakao kering yaitu biji kakao yang masiih mendapatkan perlakuan setelah pasca panen untuk proses pengeringan biji kakaonya serta membutuhkan waktu 3-4 hari untuk mengeringkan biji kakao sampai benar-benar kering.

Sesuai dengan pendapat Kacaribu, dkk (2013) bahwa alasan petani menjual biji kakao kering adalah karena harga kakao yang lebih tinggi dan tersedianya tempat penyimpanan biji kakao sehingga petani tidak perlu menghawatirkan penurunan kualitas atau kerusakan biji kakaonya.

Harga yang lebih tinggi menjadi faktor utama bagi petani yang menjual biji kakao kering. Hal ini juga di dukung dengan tersediahnya tempat penyimpanan biji kakao sehingga petani tidak menghawatirkan tempat penyimpanan biji kakaonya.

\section{KESIMPULAN}

Berdasarkan hasil penelitian dan pembahasan dapat disimpulkan:

1. Rata-rata pendapatan usaha tani kakao untuk petani menjual biji kering lebih besar dari petani yang menjual biji kakao basah dengan jumlah pendapatan petani biji kakao kering Rp 9.796.705,87 dan untuk biji kakao basah Rp 6.000.425.

2. Perbandingan pendapatan petani yang menjual biji kakao kering dengan petani yang menjual biji kakao basah nilai $\mathrm{t}$ hitung sebesar 1,205. Nilai $\mathrm{t}$ hitung $(1,205)<\mathrm{t}$ tabel $(1,697)$ dan nilai Sig. $(0,931)>\alpha(0,05)$. Artinya tidak ada perbedaan yang signifikan antara pendapatan petani yang menjual biji kakao kering dengan biji kakao basah.

\section{SARAN}

Adapun saran penulis sampaikan pada penelitian ini adalah sebagai berikut.

1. Kepada Petani

Diharapkan kepada petani agar tidak terlalu mengkhawatirkan menjual biji kakao kering dibandingkan dengan biji kakao basah karena tidak terdapat perbedaan yang signifikan terhadap harga penjualannya.

2. Kepada Pemerintah

Diharapkan kepada pemerintah agar lebih memperhatikan kebutuhan dan masalah-masalah pada petani kakao dengan cara mengadakan penyuluhan bagaiman cara menaggulangi hama dan penyakit pada tanaman kakao agar petani kakao dapat mengatasi masalah-masalah yang timbul. 


\section{DAFTAR PUSTAKA}

Badan Litbang Pertanian. 2013. Teknologi Pengolahan Primer dan Sekunder Biji Kakao. Jurnal. Jurnal Agroinovasi Edisi 20-26 Maret 2013 No. 3499 Tahun XLIII.

Effendi, Sofian. 1989, Metode Penelitian Survey. LP3ES. Jakarta.

Hanafie. 2010, Pengantar Ekonomi Pertanian. Yogyakarta: CV. Andi Offiset

Kacaribu, dkk. 2013. Analisis Perbandingan Pendapatan Petani Jagung yang Menjual Biji Basah dengan Biji Kering.Journal on Social Economic Of Agriculture and Agribusiness Vol.2, No 9. 2013

Ridwan. 2003, Skala Pengukuran Variabel-Variabel Penelitian. Cetakan Kedua, Bandung: Penerbit Alfabeta.

Soehartono. 2004. Metode Penelitian Sosial. Bandung:PT. Remaja Rosdakarya

Soekartawi. 2002. Teori Ekonomi Produksi Dengan Pokok Bahasan Analisis Fungsi Cobb-Douglas.Jakarta :PT Raja Grafindo Persada.

Widianto, Donny Dkk. 2013. Perbaikan Proses Fermentasi Biji Kakao Kering dengan Penambahan Tetes Tebu, Khamir, dan Bakteri Asam Asetat. Jurnal. Jurnal Teknosains. Vol 3 No 1 Desember 2013

Zakiya, 2012. Indonesia Targetkan Jadi Penghasil Kakao Terbesar di Dunia, Http://Nationalgeographic.Co.Id/, Diakses Tanggal 18 September 2017. 